\title{
SZEMLE
}

Educatio 27 (3), pp. 508-515 (2018)

DOI: $10.1556 / 2063.27 .2018 .3 .13$

\section{KÖZELÍTÉSEK HATVANNYOLCHOZ. VÁlogatás AZ ANGOL NYELVÜ TÁRSADALOMTUDOMÁNYI SZAKIRODALOMBÓL}

\author{
SZABÓ MÁTÉ \\ ELTE ÁJK PTI
}

Gerd-Rainer Horn: The Spirit of 1968. Rebellion in Western Europe and North America, 1956-1976. Oxford, New York, 2007. Oxford University Press. 254 p. ISBN 978-0-19927666-0

Robert Gildea, James Mark \& Anette Warring (eds): Europe’s 1968. Voices of Revolt. Oxford, 2013. Oxford University Press. 382 p. ISBN 978-0-19-958751-3

Belinda Davis, Wilfried Mausbach, Martin Klimke \& Carla MacDougall (eds): Changing the World Changing Oneself. Political Protest and Collective Identities in West Germany and the US in the 1960's and 1970's. New York, Oxford, 2012. Berghahn Books. 334 p. ISBN 978-0-85745-804-9

\section{Új tendenciák a kutatásban}

Melyek azok az irányok a teljesség felsorolása nélkül, ahol az elmúlt tíz év föképp angol nyelvü 68-as kutatása, mintegy trendként rögzíthetően, továbblépett a korábbi kutatások keretein?

Ilyen a széles perspektívájú összehasonlítás, amely mesze meghaladja az eredetileg a nyugati jóléti demokráciákra orientált szemléletmódot. Ennek a perspektívakiterjedésnek az első szakaszában, amely leginkább 1989 és az EU keleti bövítése után, de már előtte is jelentkezett, főképp Kelet- és Közép-Európa, a Nyugathoz képest a demokratikus és gazdasági fejlettség szempontjából elnyomott „keleti blokk" államai kerültek egyre inkább a kutatások előterébe, vagy egyáltalán homlokterébe. Ezzel párhuzamosan megindult a kutatás az ún. harmadik (a széles értelemben vett Nyugaton kívüli), a demokrácia és a jólét szempontjából ugyancsak hátrányos helyzetű világ '68-as mobilizációinak a kutatása (Fekete-Afrika, Ázsia, Dél-Amerika perifériás területei) az adott régiókból, országokból származó kutatók és kutatói teamek bevonásával.

A korábban a "klasszikus” jóléti demokráciákra (USA, Japán, Nyugat- és Észak-Európa) szükülő, részben éppen az ezekben az országokban lezajlott mobilizációk és tiltakozási hullámok révén a társadalomtudományokba belépő '68-as generációs kutatók - főként radikális baloldali elkötelezettségével jellemezhető 
- vizsgálatait felváltja az egyre szélesedő kutatási perspektívákat és differenciálódó módszertant felvonultató új hullám a kutatásokban. A korábbi általános, '68-cal szemben érzett szimpátia, avagy utálat visszaszorul, és az elméleti keret és módszertan szürőin át egy differenciáltabb, nem az elfogadás/elutasítás ellentétpárjára épülö hozzáállás alakul ki.

A több ország és több mozgalom 1968-as (vagy 1967-es és 1969-es) epizódjait egyetlen, bár összetett elemzési egységként konstruáló „emlékezéspolitika" ma már fél évszázados, és egyre sokszínübb. Az ötvenedik évforduló utat nyit a legkülönfélébb diskurzusoknak, amelyekben egyre inkább személyes generációs tapasztalatokkal nem rendelkező kutatók és elemzők vesznek részt, és fokozatosan visszaszorul a megemlékezés, valamint a saját élmények befolyásolta kutatások aránya. (Ez csak egy hosszabb idő alatt kibontakozó tendencia, ma még van belőlük éppen elég!)

Az 1968-as mozgalmak és mobilizációk a társadalomtudományokban persze nem szükíthetők le egyetlen évre és egyetlen homogén mozgalomra sem, szélesen értelmezik az idősávot, és sokféleképpen az ugyancsak sokféle mozgalmat. $\mathrm{A} z$ újabb kutatások, amelyek az 1968-as mozgalmakban a sokféleséget és az eltérő (politikai, gazdasági-társadalmi, kulturális) jelleget hangsúlyozzák, más-más diszciplináris orientációval, eltérő szemszögekből mást és mást előtérbe állítva, az interdiszciplináris igényességet kívánják érvényesíteni. A társadalommal és a müvészettel, kultúrával foglalkozó tudományok együttes munkáját igényelné ez a fajta interdiszciplináris kutatás. Ilyenekre ugyan ma már vannak határozott, sikeres törekvések ('́gy az itt ismertetett kötetek között is), mégis, a hagyományos diszciplináris határokat itt is nehéz átlépni. Így azután hol a politikai, hol a müvészeti-kulturális oldal kerül előtérbe az egyes monográfiák, tanulmánykötetek anyagaiban, jó esetben kiegyensúlyozottan, a tanulmányok egymást kiegészítő összhatásának szintjén. E tekintetben az itt tárgyalt kötetek megközelítésmódja példás.

\section{Összehasonlító társadalom- és politikatörténet}

A közvetlen demokratikus kísérletezést látja '68 „szellemének”, illetve az ebből az időszakból aktuálisnak bizonyuló üzenetnek a mai demokráciák válságainak és problémáinak a kezelésére Gerd-Rainer Horn az 1968 szelleme. Tiltakozások az USA-ban és Nyugat-Európában (2007) című monográfájában. Horn társadalomtörténész, aki különféle 20. századi témákban publikált monográfiákat, úgymint a nyugat-európai munkásmozgalom története vagy a katolikus egyház társadalmi tanítása, és szerzőtársakkal már a jelen monográfia mellett is foglalkozott a '68-as mozgalmakkal külön kötetben.

A kötet összehasonlító mozgalomtörténeti monográfia, amely kitűnően, emellett olvasmányosan, szórakoztatóan van megírva, széles történeti és összehasonlító perspektívában tárgyalja a témát. A hagyományos nagy modellek - USA, Franciaország, Németország (NSZK) mellett a kötet jó kitekintést ad Spanyolország, néhol Portugália és a szerző lakóés időnként munkahelyéül szolgáló Belgium és Hollandia '68-as mozgalmaira és konfliktusaira. A kötet a nonkonformista előzményeket, a diákmozgalmakat és a munkások sztrájk- és egyéb küzdelmeit kíséri végig a kiválasztott országokban, húsz év (1956-1976) perspektívájában. A mozgalom látenciáját, kevésbé látványos előkészületeit, a művészeti-politikai irányzatok szellem- és társadalomtörténetét, illetve a rock- és popkultúrák müvészettörténetét dolgozza fel részletekbe 
menő dokumentációval és imponáló hozzáértéssel. A kötet egy valóban interdiszciplináris társadalomtörténeti keretben kapcsolja össze azokat a szálakat, amelyek országonként eltérő idődimenzióban (az NSZK-ban már 1967-ben, Olaszországban egészen a hetvenes évekig) eredményeznek mozgalmi, „fehéren izzó” (white hot), hirtelen és látványos mobilizációt, politikai és társadalmi csúcsfeszültséget és a „biztosítékok” időszaki kivágását - hogy az áramszolgáltatás, a társadalom normálfolyamata, megfelelő javítgatás után, újra megindulhasson, de más, megváltozott, új „feszültségekkel”. Így például a feminizmus az USA-ban és az NSZK-ban egyaránt a diákmozgalmak belső konfliktusából termeli ki a széles társadalmi hatást gyakorló új „növendékmozgalmát”.

A diákság társadalmi szerepének profilírozása a kortárs nyugati felsőoktatás struktúráinak és problémáinak elemzéséből nő ki a kötetben, de világossá teszi a szerző, hogy - a felsőoktatási politika megváltoztatásán túl - nyilvánvalóan az össztársadalmi, gazdasági és kulturális változás igénye vezérelte a diákokat, és az egyéb a mobilizációba bekapcsolódó csoportokat (főként a nagyipari munkások és a kreatív szabad foglalkozású művészek és tudósok kapnak szerepet Horn értelmező modelljében).

Ezt követően kerül sor az ötödik fejezetben az új részvételi demokratikus modell kialakulásának bemutatására, és annak a tézisnek a megfogalmazására, miszerint ilyen típusú modellek állnak a demokrácia megújítása mellett elkötelezett 1968-as társadalmi mozgalmak elöterében. A demokratikus mozgalmak és a demokratizálódás kapcsolatának kritikusabb elemzői szerint a demokratikus jogok igénylői nem mindig folytattak igazán inkluzív és demokratikus gyakorlatot szervezeteik belső döntéshozatalában. Az 1968-as mozgalmakban még élt a bolsevik típusú pártból elindult új típusú munkáspárt mítosza, ráadásul akkoriban még nem voltak ismeretesek a mai civil mozgalmak szélesebb demokratizálódását biztosító modern kommunikációs technológiák sem.

Érvekkel nem eléggé megtámogatottnak tartom a kötet konklúziójában a'68-as mozgalom és a demokratikus reform, átalakulás ilyen közvetlennek feltételezett aranymetszési pontját. Ez az igény szemléletileg valóban jelen volt a 68-as mozgalmakban, de a gyakorlat problémáiból más képet kaphatunk erröl. Példaként említhető az új feminizmus, amely a diákmozgalmat macsóizmussal, a nőket kirekesztő gyakorlat fenntartásával kritizálta, és kapott széles lehetőségeket eme érvelés alapján a későbbi látványos további fejlődésre.

A másik probléma a '68-as mozgalmak némelyikének viszonya az erőszakhoz. $\mathrm{A} z$ állami erőszakmonopólium gyakorlati megkérdőjelezése (és ennek elméleti előkészítése, az ún. politikai forradalmi stratégia) már önmagában a demokrácia veszélyeztetését jelenti. 1968-ban az újbalos mozgalmakban (Mao, Marcuse, Guevara, Fanon és mások nyomán) még valamiféle erőszakos forradalmi mítosz müködik, ezzel állítják szembe a későbbi, az ellenkultúrára és nem az új baloldalra épülő alternatív mozgalmak az erőszakmentes civil társadalmi átalakulás programját. 1968 valóban radikális és sokszor erőszakos tiltakozási potenciálokat szabadított fel a nyugati társadalmak egy részében. Hosszú időre bevetté vált a radikális, a rendfenntartókkal szembeni ellenállással párosuló tüntetési kultúra, mint például Olaszországban. Ez majd a nyolcvanas évek mozgalmaiban kerül leváltásra az akkor újrafogalmazott stratégiai koncepció, a civil társadalom erőszakmentes ellenállása és a polgári engedetlenség kultúrája révén. A repressziónak a '68-as mozgalmakon belüli jelenléte nyilvánvaló 
a terrorizmus esetében, de a feminista társadalomkritika is épp azt hangsúlyozza, hogy a diák- és a kommunális mozgalmak nem alakították át a szexizmus és patriarchaizmus mintáit, és az új családmodellek ugyancsak a nők elnyomását vagy akár a gyermekek veszélyeztetését is jelenthették a családon belüli szexuális erőszak révén. A konzervatív kritikák ezen a ponton nem tekinthetők csupán ideologikusnak, és a fentiek árnyékot vetnek a '68-as közvetlen demokratikus modellek egyébként önmagukon belül is igen problematikus jellegére.

Nagy erénye a kötetnek a széles összehasonlítás, azon belül pedig az atipikus és kevésbé ismert spanyol, portugál és belga fejlődés alapos tárgyalása és az ellenkultúra és az új baloldal profiljának kialakulásához vezető politikai folyamatok összekapcsolódásának igen alapos elemzése. A kötet első fejezeteiben parádésan megvalósul a szintézis interdiszciplináris egyensúlya az elemzésben, és mindvégig jól érvényesül a hosszabb távú társadalomtörténeti, politikai és kultúrtörténeti szemlélet.

A Habermas óta kötelező nyilvánosságelemzések is jól láttatják a fiatalok rockkultúrájának fórumai (klubok, fesztiválok, ünnepek) és a politikai jellegü tiltakozások (tüntetések és sztrájkok) közötti kapcsolatokat. Az elemzés plasztikusan ábrázolja az „anti”-célokat, a meglévő struktúrák (család, egyetem, állam, vállalat, színház stb.) elutasítását, a mozgósítást elősegíto "negativizmust”, azt, hogy az elutasításban mint közös nevezőben mindenki egyetértett.

\section{Összehasonlító szocializációs felmérés 1968-ról Európában}

Az Európa 1968-a. A forradalom hangjai c. kötet egy igen érdekes kutatási projekt alapján készült, több szerkesztővel és fe- jezetenként több szerzővel. A 11 fejezet a bevezetéssel és a konklúziókkal összesen 40 szerzői szerepkörre utal, amely szerepek 14 szerző és szerkesztő között egyenetlenül oszlanak el: van olyan szerző/szerkesztő (James Mark, az Exeteri Egyetem történészprofesszora), aki hat alkalommal szerepel valamely részfejezet munkatársaként. A 14 szerző közül hárman dolgoznak Közép-Európában (Prága, Budapest, Varsó).

A kötet, amelynek egyik célkitűzése, hogy 1968 európai egységét érzékeltesse, hogy bemutassa a két részre, keleti és nyugati területekre szakított kontinens összetartozását, korábbi aktivistákkal készített interjúkra, civil és politikai szervezetekkel folytatott konzultációkra és más forrásokra épül. Az interjúk és konzultációk összesen 15 országban készültek, a volt Szovjetuniótól kezdve Izlandon át egészen az NDK-ig és Spanyolországig. A mintegy 500 interjúból kb. 25 készült magyarokkal, ismert volt ellenzéki, diszszidens aktivistákkal, akik - egyetlen kivételtől eltekintve - mindannyian nevesítve vannak. Hét egykori ellenzéki szervezet tagjaival konzultáltak („maoisták”, balatonboglári kápolnatárlatok, budapesti iskola, Lukács-kör, Orfeo művészcsoport, Regnum Marianum, KISZ-reformerek). Az egyéni interjúk és a szervezeti tagsággal folytatott konzultációk között átfedések vannak (pl. Haraszti Miklós, Heller Ágnes, Galántai György).

A kutatói team egyik célja volt a korábbi, néhány főbb városra (pl. Párizs, Frankfurt) koncentráló vizsgálatok decentralizálása, ami igencsak indokolható, tekintettel a vezéreszmére, az egységes 1968-as Európa-kép kialakítására. Az interjúk és azok feldolgozása az oral history módszer és iskola jól átgondolt és a projektre alkalmazottan kialakított koncepciójára épült. Az aktivistákkal készített interjúk feldolgozása a szocializációs és 
csoportszerkezeti szempontok egyesítésével történt. $\mathrm{Az}$ olvasót szocializációs és strukturális csomópontok orientálják, három részre osztott tíz fejezetben.

Első rész: Aktivistává válni, Ráébredések, Családok, Inspirációk.

Második rész: Aktivistának lenni, Forradalmak, Találkozások, Terek, Kiszakadók (drop-outs), Hitek, Gender és szexualitás, Erőszak.

Harmadik rész: $\mathrm{A} z$ aktivizmus értelmezése (making sense): Reflexiók.

$\mathrm{Ez}$ az értelmezési keret komplex, és jól átgondolt. A struktúrák és folyamatok kapcsolatára épülő, szocializációs és komparatív-interdiszciplináris szemléletmódja nagyon jól sikerült szintézist eredményez a kötetben.

Álljon itt a tizedik, az erőszakkal kapcsolatos fejezet néhány problémája, amely kérdéskört fentebb, Horn munkája alapján már érintettünk. A kutatók az erőszak sikamlós kérdését megfelelő kategóriarendszerrel elemzik, lehetőleg az összes ország tapasztalatát (interjúkat és szervezeti konzultációkat) tekintetbe véve. Néhány, a téma szempontjából fontos ország kiemelt tárgyalást élvez, mivel ezekben a demokratizálódás folyamán bizonyos mértékig igazoltnak volt tekinthető a diktatórikus rezsimekkel szembeni ellenerőszak alkalmazása (pl. Spanyolország és Görögország, avagy Észak-Írország, ahol minden az egymást erősítő etnikai és vallási konfliktus mentén szerveződött meg). $\mathrm{A} z$ aktivisták szerepmodelljei belsőleg konfliktusosak voltak, és a mozgalmakban (Nyugaton legalábbis) eltérő mértékben, de jelen volt az erőszakos és az erőszakmentes irányzatok közötti feszültség.

A politikai erőszak igazolását szolgálhatta bizonyos államokban, autoriter rendszerekben a már említett diktatórikus elnyomás, ám másutt, a demokratikus rendszerekben, nem a politikai rendszer jellege, hanem a forradalom melletti el- kötelezettség vezette az erőszakot vállaló csoportokat. Az erőszak vagy erőszakmentesség stratégiája a mozgalmak belső vitáiban, illetve a velük foglalkozó politikai diskurzusban, a médiában is megjelent.

A szerzők kitűzött célja (a kontinentális egységre, a strukturális és processzuális megközelítések egységére való törekvés) megvalósult a kutatásban. A konklúziókban a szerkesztők kiemelik az antiimperializmus átfogó és integratív jellegét, a politikai múlt feldolgozását az emlékezetpolitikai mulasztások ellenére - ez föleg a náci hagyományt és az újraegyesített Németországot érinti, de jelen van Franciaországban, Spanyolországban és a posztkommunista államokban is. A transznacionális kapcsolatrendszer és a diffúziós folyamatok a globális mozgalmak korában az elemzés kiemelkedő aspektusát jelentik, föképp a kulturális tőkeáramlás vonalán, és az erőszak és a forradalom körüli viták egészen a később teret nyerő erőszakmentes alternatív mozgalmak megjelenéséig jelen vannak. 1968 ma Európában mindenütt, bár eltérő mértékben, a történeti emlékezet és a politikai kultúra hagyományának a része.

\section{Német-amerikai összehasonlítások}

A négyfős szerzői kollektíva által szerkesztett Megváltoztatni a világot - megváltoztatni magunkat. Politikai tiltakozás és kollektiv identitások Nyugat-Németországban és az USA-ban az 1960-as és az 1990-es években címmel megjelent kötet egy, a Heidelbergi Egyetem (Heidelberg Center for American Studies) által szervezett és a Volkswagen Alapítvány által finanszírozott konferencia publikálása. $\mathrm{A} z$ USA-t és az NSZK-t elméleti és mozgalmi szempontok szerint összehasonlító tanulmányokat tartalmaz. Olyan kérdé- 
seket vizsgál, mint például a frankfurti iskola és a '68-as mozgalmak viszonya, avagy az USA és az NSZK külpolitikája számára felvetett kihívások a két ország diáktiltakozásai révén.

Folytatva a többi kötet ismertetésén végigvonuló, korábban már megkezdett szálat, az erőszakprobléma előtérbe állítását, Ingrid Gilcher-Holtey tanulmányát, $A z$ új baloldal és az eröszakot emelném ki. Itt is felvetődik a kérdés, hogy mit tekintsünk valójában erőszaknak. Ahogyan szerzőnk, aki Németországban és nemzetközileg is egyike a legismertebb és elismertebb történész szerzőknek (eddig főleg Franciaországgal foglalkozott, de a mostani évfordulóra németül egy kicsi, de átfogó és igen tartalmas nemzetközi öszszehasonlító monográfiát jelentetett meg a témában) fogalmaz:

"Az új baloldal szimbolikusan anticipálta és cselekvéssé formálta Foucault igényét a hatalom leleplezésére és a Leviatánon túli világ megmutatására. A batalom decentralizált értelmezése és az eröszak kiterjesztett felfogása segitette az új baloldalt, bogy társadalomelméletében megjelenitse a hatalmi viszonyokat, valamint az eröszakot a mindennapokban, a családban és a nemek közötti viszonyban. Így új és finomabb megközelitések jelentek meg az eröszak kritikájában: szimbolikus erőszak, kulturális erőszak, rituális eröszak és végül, de nem utolsósorban: szexuális eröszak. Ezek mind helyet kaptak az új baloldal társadalomkritikájában, és a 21. század jogfelfogását is átformálták." (167. o.)

Jómagam bizonyosan bevontam volna az elemzésbe Johan Galtung strukturális erőszakkal kapcsolatos koncepcióját, ami fontos volt a mozgalmi ellenerőszak elméletének alakulása, mobilizálása szempontjából is. Ugyancsak az új baloldal egyik elismert elemzője, George Katsiaficas állítja élére a témát a kötetben Szavazatok és golyók között címet viselő tanulmányában, ahol főleg az utcai erőszakot alkalmazó autonómok és a városi gerillák gyakorlatát elemzi két országban (USA és NSZK).

$\mathrm{A} z$ erőszakalkalmazás és az állami erőszakmonopólium a '68-as újbalos és ellenkulturális irányzatok különbségének középponti eleme. Az új baloldal a marxi-lenini forradalomelméletet - Herbert Marcuse, Ernesto Che Guevara, Franz Fanon, Ho Shi Minh és Fidel Castro nyomán - radikalizálta, az ellenkultúra viszont az alulról jövő civil társadalmi, az erőszakmentességet hirdető Mahatma Gandhi és Henry David Thoreau által fémjelzett állampolgári engedetlenség vonalakat követte. Jürgen Habermas, aki a konszenzuális, a hatalommentes diskurzus és az ésszerü politikai konszenzuskeresés gondolatát fejti ki politikai filozófiájában a kilencvenes években, már akkor, 1968-ban elhatárolta magát az erőszakos forradalmi gondolattól, és későbbi műveiben az új, alternatív erőszakmentes társadalmi mozgalmakkal vállalt politikai közösséget (ökopax, új feminizmus).

Ugyanakkor azonban tagadhatatlan, hogy a diák-, új baloldali és ellenkulturális mozgalmakat összességükben jellemezte az a fajta antiimperializmus, amely alkalmas volt - a masszív háborús erőszak megakadályozása és a civil lakosság védelme érdekében - az ellenállás és annak radikális formáinak elfogadására és elfogadtatására a radikálisok körében. Hiszen épp az USA vietnami háborúja elleni tiltakozás volt az egyik átfogó téma, amely a marxi-lenini világrendszer és imperializmuselmélet megújításához vezetett a társadalomtudományokban is. $\mathrm{A} z$ antiimperializmus mind az erőszakos forradalom, mind az erőszakmentes társadalmi átalakulás mellett elkötelezett csoportokat mobilizálta az imperialista világrendszer vezetője, a vietnami háború folytatója, az USA ellen. A militáns antiimperializmusnak és az antimilitarista, békemozgalmi filozófiának egyaránt volt 
mainstream hatása, gondoljunk a polgárjogi mozgalmakban gyökerező brit és az USA-beli hippi- és rockkultúra hatására a beat-és rockzenében, a filmművészetben és irodalomban. (Bár az ellenkultúra, a rockkultúra is rendelkezett erőszakos leágazásokkal, gondoljunk a Manson család rémtetteire, vagy a Hells Angels és hasonló klubok, hálózatok körében és fóképp a közöttük megjelenő erőszakra koncerteken, találkahelyeken. Említhetnénk továbbá a Warriors [Harcolók, Harcosok - Sz. M.] c. filmet, amelyet erőszakos tartalma miatt nem vetítettek Magyarországon.) A '68-as mozgalmak erőszakos, terrorista irányai, amelyek, a Marxtól származó forradalomelmélet alapján, az antiimperialista küzdelmet a jóléti-demokratikus mindennapokban kívánták megvalósítani, sok nyugati országban egészen a hetvenes évekig - gyakran még tovább is - kihívást jelentettek a demokrácia és politikai kultúrája számára - nem csupán Európában, de globálisan is.

A kötet német-amerikai tengelyen kiteljesíti az azonos és a különleges, sajátos tendenciák megmutatását: így az NSZK-ban a 68-as mozgalmak hatására oly fontossá, és megkerülhetetlen kötelezettséggé változtatott szinte mindennapos emlékezést a Holocaustra és annak a kortárs német társadalomra származtatott felelősségi viszonyaira a magán- és közintézményekben. Ez minden bizonnyal egyike a német sajátosságoknak, akárcsak a súlyos teoretikus, filozofikus vitatkozás, vagy a két német állam elválasztása miatti - nemzeti egység hiánya az 1968-as megemlékezésekben.

$$
* * *
$$

Összességében megállapíthatjuk, hogy a három kötet, különféle megközelítésekkel (monográfia, nemzetközi felmérés, bilaterális összehasonlítás) egyaránt hasznosnak és példamutatónak tekinthető az 1968-as mozgalmak egyre szélesedő angol nyelvü irodalmában. Azonban 1968 nem csupán a fejlett ipari társadalmakban rendelkezett mobilizáló erővel, hanem mindenütt, ahol a bürokrácia kiépítéséhez kialakították a tömeges egyetemi képzést, melynek diákjai nem kívántak vagy nem tudtak elhelyezkedni az ő közremüködésükkel felépített „kafkai kastély” rendszerében, hanem fellázadtak a bürokratikusautoriter rendszerek ellen, mind KeletEurópában, mind egy sor posztkoloniális rendszerben Afrikában és Dél-Amerikában.

1968 „korszakos” határ volt, mert lezárt egy korszakot, és megnyitott egy újat. Leváltotta a második világháború utáni hidegháborús korszak „fordista”, a gyári és hivatali fegyelemre, diszciplínára épülő, mindenféle utópiát, kreativitást, és nonkonformizmust elnyomó, a növekedés és jólét orientálta társadalmát és kultúráját. A korábbi időszaknak a társadalmi kísérleteket kizáró, megbélyegző, magas konformitási kényszert követelő rutinizált „Szörnyeteg” világával áll szemben az új, posztindusztriális kor „Szzépsége”. Ronald Inglehart úgy vélte klasszikus művében, a Csendes forradalomban (1977), hogy az új generáció új értékrendet, kultúrát és új globális és belpolitikai konfliktusvonalakat jelenített meg a hatvanas években, azaz a strukturális változások hordozója volt, még akkor is, ha résztvevők és aktivisták, akárcsak követőjük közül sokan, később elhatárolták magukat '68-tól, mint az „őrület momentumától" (moment of madness), a kellemesebbé alakított posztindusztriális mindennapok élményközpontú luxusra épülő nyugati kényelmében. Így falta fel a forradalom a gyermekeit, konformistává változtatta őket a hetvenes-nyolcvanas évek növekedésre alapozott jóléte révén, egyben viszont új mozgalmaknak, a zöldeknek és az átalakult békemozgalomnak nyújtott teret a fejlett országokban a nyolcvanas években 
- kialakítva a posztindusztriális (1968) és a posztmaterialista (nyolcvanas évek) mozgalomtípust, amely már elutasította a korábban oly központi marxizmust és annak forradalomelméletét, illetve a munkásmozgalmi hagyományt - az új középosztály vezetőereje révén viszont felvállalta a polgárjogi hagyományt. $\mathrm{Az}$,új mozgalmi család" tehát '68 örököse, de nem folytatója, hanem mint Horn véli, újragondolója a civil, közvetlen demokrácia üzenetének egy új társadalmi-politikai kontextusban (jóléti állam, növekedés, parlamentarizmus válsága, civilizációs és ökológiai válságok). 